\title{
The short and long-term implications of warming and increased sea water pCO2 on the physiological response of a temperate neogastropod species
}

Maria Loreto Mardones ( $\nabla$ mlmv1c20@soton.ac.uk)

University of Southampton https://orcid.org/0000-0001-5216-4240

Sven Thatje

University of Southampton

Phillip Fenberg

University of Southampton

Chris Hauton

University of Southampton

\section{Research Article}

Keywords: Oceanic Uptake of Atmospheric Carbon Dioxide, Marine Ectotherms, Long-term Exposure, Reproduction

Posted Date: March 15th, 2021

DOl: https://doi.org/10.21203/rs.3.rs-183920/v1

License: (c) (i) This work is licensed under a Creative Commons Attribution 4.0 International License. Read Full License

Version of Record: A version of this preprint was published at Marine Biology on November 20th, 2021. See the published version at https://doi.org/10.1007/s00227-021-03990-0. 


\section{Abstract}

Global average temperatures and sea water $\mathrm{pCO}_{2}$ have rapidly increased due to the oceanic uptake of atmospheric carbon dioxide producing severe consequences for a broad range of species. The impacts on marine ectotherms have been largely reported at short-term scales (i.e. from days to weeks); however, the prolonged effects on long-term processes such as reproduction have received little attention. The gastropod Ocenebra erinaceus is a key predator structuring communities on rocky shores of the French and UK coasts. Even though rocky shore species are regarded as being very tolerant to changes in temperature and $\mathrm{pH}$, many of them are living near their upper tolerance limits, making them susceptible to rapid environmental changes. Here, we report that future mean sea water conditions (RCP8.5, $+3^{\circ} \mathrm{C}$ and $\sim 900 \mu \mathrm{atm} \mathrm{CO}_{2}$ ) do not significantly affect the physiology and molecular response of 0 . erinaceus adults after 132 days. During the first fifty-days, there was a slight impact on oxygen consumption rates and body weight; however, after ninety-five days of exposure, gastropods relied on food resources to fully acclimate to the experimental condition. Despite this, it was after long-term exposure ( 10 months) reproduction ceased in females exposed to these future sea water conditions. Therefore, in the short-term O. erinaceus appear to be capable of full compensation; however, in the long-term, they fail to invest in reproduction. Future research should take into account the combined results from both, short- and longterm effects to improve our projections of the ecological consequences of climate change.

\section{Introduction}

Anthropogenic greenhouse gas emissions (i.e. carbon dioxide $\left(\mathrm{CO}_{2}\right)$, methane $\left(\mathrm{CH}_{4}\right)$, nitrous oxide $\left(\mathrm{N}_{2} \mathrm{O}\right)$ have risen to unprecedented levels (Gattuso et al., 2015) producing changes in the weather, air and seasurface temperatures, sea level and sea water $\mathrm{pCO}_{2}$ (and hence pH), amongst others (IPCC 2013). Carbon dioxide is one of the most important greenhouse gases in terms of its effects on climate change (e.g. regulating Earth's surface temperature) and in regulating the chemistry of the global ocean. To date, $\mathrm{CO}_{2}$ emissions into Earth's atmosphere has accelerated from 280 ppm in the pre-industrial period to 410.27 ppm at November 2019, according to the Mauna Loa Observatory $\mathrm{CO}_{2}$ record (NOAA). The oceans have absorbed $\sim 30 \%$ of the atmospheric $\mathrm{CO}_{2}$ into: carbonic acid $\left(\mathrm{H}_{2} \mathrm{CO}_{3}\right)$, bicarbonate ions $\left(\mathrm{HCO}_{3}{ }^{-}\right)$and carbonate ions $\left(\mathrm{CO}_{3}{ }^{2-}\right)$; however, this process also releases free hydrogen molecules $[\mathrm{H}+]$ (Doney et al., 2009; Feely et al., 2004). The increase of $\mathrm{H}+$ concentration produces a process that has been termed 'ocean acidification' (OA). By the end of the twenty-first century, it has been predicted that the sea surface pH will decrease by 0.33 ( \pm 0.003) units (Bopp et al., 2013; Orr et al., 2005).

To date, it is well known that increases in sea water $\mathrm{pCO}_{2}$ produces negative effects in marine animals, especially in calcifying organisms, reducing growth, survival, reproduction and shell mineralization, amongst others (Barton et al., 2012; Dupont et al., 2013; Kroeker et al., 2010; Parker et al., 2013). In addition, and due to the atmospheric $\mathrm{CO}_{2}$ level increase, global sea temperatures are also rising, with an 
expected increase of $2.73( \pm 0.72)^{\circ} \mathrm{C}$ by the end of this century (Bopp et al., 2013; Meinshausen et al., 2011). An increase of temperature outside of the thermal tolerance range affects the metabolic rate of marine ectotherms, causing a rapid deterioration of cellular processes and affecting whole-organism physiology (Pörtner, 2008). However, the combined effect of temperature and $p \mathrm{CO}_{2}$ on marine ectotherms has been difficult to predict because, at the metabolic level, increased temperatures produce an increase in metabolism and pH/hypercapnia can induce metabolic depression (Michaelidis et al., 2005; Kroeker et al., 2013). Thus, when both stressors temperature and elevated $\mathrm{pCO}_{2}$ act simultaneously, the effects can be either synergistic or antagonistic (Crain et al., 2008; Harvey et al., 2013; Kroeker et al., 2013).

The long-term survival of marine ectotherms largely depends on how fast they can acclimate or adapt to environmental changes (Hofmann and Todgham, 2010). Phenotypic plasticity has been identified as one of the most powerful mechanisms to adjust to climate change (Nagelkerken and Munday, 2016). During short-term exposure to stressful conditions, phenotypic plasticity facilitates the persistence of a population, as a possible acclimation to the environmental conditions (Foo et al., 2012; Kelly et al., 2012). However, physiological compensatory mechanisms develop over prolonged periods, often resulting in differential trade-offs, because the acclimation to one physiological function can result in a significant cost to another function. For example, Goldbold and Solan (2013) did not detect any effect on the physiology of a non-calcifying marine polychaete, Alitta virens, when exposed to warming and acidification for a short period. However, after 18 months, the organism's physiology was affected, showing negative effects on growth and behaviour, which in the long term can affect ecosystem functioning. In marine gastropods, few works have assessed the long-term effects of acidification and warming. Research has focused on impacts on shell bio-mineralization and morphology (Rühl et al., 2017), feeding physiology and behaviour (Chatzinikolaou et al., 2019; Zhang et al., 2015); however, no study has assessed the combined effects of short- and long-term exposure to climate change in the physiology of marine gastropods.

The principal aim of this study was to measure the short and long-term effects of temperature and $\mathrm{pCO}_{2}$ increases expected for the end of this century according to RCP8.5 IPPC $2013\left(+3^{\circ} \mathrm{C}, \sim 900 \mu\right.$ atm $\mathrm{CO}_{2}$ ) on the physiological and molecular response (at 135 days) and reproductive investment (at 10 months) of a temperate neogastropod. Ocenebra erinaceus, also known as "oyster drill", is a predator of rocky coastal environments that inhabit the Atlantic coast of UK and France (Smith et al., 2015). Rocky shore species are regarded as being particularly tolerant to the impacts of future ocean conditions; however, many of them are living near their upper tolerance limits, which makes them highly susceptible to rapid environmental changes (Somero 2002). Understanding how rocky shore organisms will compensate for the effects of climate change over extended periods will improve our projections of the ecological consequences of climate change in this globally distributed intertidal habitat. 


\section{Material And Methods}

Animal collection and maintenance

Ocenebra erinaceus adults (30 - $40 \mathrm{~mm}$ shell length) were collected by hand from the low intertidal in the Solent, UK $\left(50^{\circ} 51^{\prime} \mathrm{N}, 001^{\circ} 21^{\prime} \mathrm{W}\right)$. After collection, specimens were transferred to the National Oceanography Centre, Southampton, UK (NOCS), fed ad libitum with mussels and maintained for thirty days prior to experimentation under laboratory conditions $\left(14-15^{\circ} \mathrm{C} ; 33-34 \mathrm{psu}\right)$. Then, gastropods were transferred to one of the two experimental conditions: control $\left(14{ }^{\circ} \mathrm{C}-400 \mu\right.$ atm $\left.\mathrm{CO}_{2}\right)$ and future conditions $\left(17^{\circ} \mathrm{C}-900 \mu\right.$ atm $\mathrm{CO}_{2}$, representative of a future IPCC RCP8.5 scenario (IPCC 2013).

Temperature and $\mathrm{CO}_{2}$ system

The ' $\mathrm{CO}_{2}$ system' was designed following the methodology described by Hauton et al., (2009) and Riebesell et al., (2011). Two experimental systems were set up: two control tanks $\left(14^{\circ} \mathrm{C}\right.$ and pH $8.0 \sim 400$ ppm of $\mathrm{CO}_{2}$ ) and two $\mathrm{CO}_{2}$ injection tanks $\left(+3{ }^{\circ} \mathrm{C}\right.$ and pH $7.7 \sim 900 \mu$ atm $\left.\mathrm{CO}_{2}\right)$. Each tank, comprised a 'mixing tank' ( $50 \mathrm{~L})$ and separate 'incubation tank' $(20 \mathrm{~L})$ that were maintained constantly -using water bath- at 14 or $17{ }^{\circ} \mathrm{C}$, respectively. Seawater was mixed between the mixing and incubation tanks with a peristaltic pump and was continually aerated. In the $\mathrm{CO}_{2}$ injection tanks, $\mathrm{pH}$ was adjusted using AquaMedic $^{\mathrm{Tm}} \mathrm{pH}$ computers with calibrated electrodes. Temperature and salinity were measured every two-days with a EC170 meter and pH was measured three times per week using a three-decimal-place SevenMulti $\mathrm{pH}$ meter. Water samples were taken and fixed using mercuric chloride every fortnight in control and $\mathrm{CO}_{2}$ system mixing tanks, according to Riesbell et al., (2001). Total alkalinity $\left(A_{T}\right)$ and dissolved inorganic carbon (DIC) were determined to characterize the carbonate chemistry in each tank, using VINDTA $3 \mathrm{C}$ following standard protocols at the carbonate facility at NOCS. $\mathrm{pCO}_{2}$ was calculated from measured $\mathrm{pH}, \mathrm{A}_{\mathrm{T}}$, temperature and salinity using CO2calc (Lewis and Wallace 1998). The seawater conditions for adult physiology experiment are summarised in Table 1.

Short-term exposure ( 0 - 135 days)

Forty gastropods were exposed to control and climate change conditions and measured at regular intervals of $0,15,50,95$ and 135 days to observe the physiological impact on growth, weight, ingestion, routine metabolic rate, and $h s p 70$ gene expression. Shell growth (in $\mathrm{mm}$ per day) and weight (in grammes 
per day) were monitored. Ingestion rate was determined according to Navarro et al. (2002). Routine metabolic rate (RMR) was determined in hermetically sealed chambers with a pre-calibrated oxygen sensor attached to the inner wall (FIBOX, PreSens fiber optic equipment calibrated according to manufacturer's protocols) filled with $365 \mathrm{ml}$ of filtered seawater $(0.5 \mu \mathrm{m}$ and salinity 33-34), saturated at $100 \%$ oxygen and at the same temperature and $\mathrm{CO}_{2}$ concentration of experimental conditions.

Hsp70 gene expression (short-term exposure)

For the molecular analysis of changes in the expression of $70 \mathrm{kDa}$ heat shock protein, degenerate primers were first designed to isolated 0 . erinaceus-specific genes sequences for $h s p 70$ gene and two endogenous reference genes for quantitative real-time PCR: glyceraldehyde-3-phosphate dehydrogenase (gapdh gene) and $\beta$-actin ( $\beta$-act gene). Degenerate primers were designed based on conserved regions that were identified from protein sequences alignments of theusing CLUSTAL Omega (needs a citation). Each alignment was examined and any mismatches were corrected manually. For $h s p 70$, degenerate primers (sense 5'- GAYATGAARCAYTGGCCNT-3', antisense 5'-TANGCNCANGCYTCRTCNG-3', Tm=58 ${ }^{\circ} \mathrm{C}$ ) were designed against an amino acid alignment of 7 molluscan heat shock sequences. For gapdh (sense $5^{\prime}$-CNCCCNATGTTYGTNRTNGG-3', antisense 5'-ATNCCNGCNYYNGCRTCRAA-3',Tm=59 ${ }^{\circ} \mathrm{C}$ ) and $\beta$-act (sense 5'-ATGGTNGGNATGGGNCARAA-3', antisense 5'-TCYTTYTGCATNCKRTCNGC-3', Tm=57 ${ }^{\circ} \mathrm{C}$ ) gene, degenerate primers were designed against an amino acid sequences of 4 , and 10 sequences, respectively (Table 2). Primers were synthesized by Eurofin MWG operon (Ebersberg, Germany).

Degenerate primers were used in a conventional PCR reaction to isolate fragments of each gene. PCR reactions were performed according to the manufacturer protocol using $0.25 \mu$ of GoTAq DNA polymerase ( $5 \mathrm{u} / \mu \mathrm{l}$; Promega Corporation), $2 \mu \mathrm{M}$ of each of sense and antisense degenerate primers and $1 \mu \mathrm{l}$ of template cDNA (whole-tissue snails) in a final volume of $25 \mu \mathrm{l}$ with the following PCR cycle conditions: 1 cycle of $95^{\circ} \mathrm{C}$ for $2 \mathrm{~min}, 35$ cycles of $\left[95^{\circ} \mathrm{C} 1 \mathrm{~min},{ }^{\prime} \mathrm{AT}{ }^{\circ} \mathrm{C} 1 \mathrm{~min}, 72^{\circ} \mathrm{C} 30 \mathrm{~s}\right.$ ], followed by $72^{\circ} \mathrm{C}$ for $8 \mathrm{~min}$ ( 'AT' = annealing temperature of each pair of degenerate primers). PCR products obtained from degenerate PCR were gel-purified and potential positive gene fragments were cut from agarose gel $(1 \%$ agarose). The DNA from the gel was extracted using QIAquick® Gel extraction kit (Qiagen Ltd. UK) following the manufacturer's protocol. Extracted PCR products were cloned using the PGEM®-T Easy Vector cloning kit (Promega Ltd.). Plasmid DNA was isolated from three bacterial colonies using the Qiaprep Spin Miniprep kit (QIAGEN) and sequenced using vector-specific (M13) primers by SourceBioscience LifeScience, Nottingham. The nucleotide sequences were used to deduce amino acid sequences for each gene fragment and these were compared against the ENA database search engine using a BLAST sequence similarity search. 
Total RNA was extracted from gills from control and climate change gastropods using TRI reagent (Sigma Aldrich) following the manufacturer instructions. RNA purity was confirmed by analysing the $A_{260} / A_{280}$ ratio (ND-1000 spectrophotometer, thermo Scientific) and RNA integrity and quantity was measured by an automated capillary electrophoresis system (Experion Bio-Rad laboratories) with StdSens chips and reagents. Genomic DNA contamination of total RNA samples was removed before cDNA synthesis; $4 \mu \mathrm{g}$ total RNA was treated following the manufacturer's protocol (Promega Corporation). DNASE-treated total RNA was then reverse transcribed using Superscript III reverse transcriptase (Invitrogen, UK) according to the manufacturer's protocol.

For the Quantitative real-time PCR analysis, qPCR primers were designed based on the nucleotide sequences for each gene obtained from cloning and sequencing. Each primer pair was designed using PrimerQuest Tool (Integrated DNA Technologies) according to the recommended criteria. The sequences of the primers are summarised in Table 3. All real time qPCR reactions were performed in a LightCycler 96 (Roche, Switzerland); each $22 \mu \mathrm{l}$ reaction contained: $12.5 \mu \mathrm{l}$ of Precision Plus 2x qPCR Master mix with SYBR green (PrimerDesign, UK), $2 \mu$ of each primer and $2 \mu$ of template cDNA with the following PCR conditions: 1 cycle of $95^{\circ} \mathrm{C}$ for $5 \mathrm{~min}, 40$ cycles of $\left[90^{\circ} \mathrm{C} 10 \mathrm{~s}, 60^{\circ} \mathrm{C} 1 \mathrm{~min}\right]$. Each gene was run in duplicate in 96-plates and NTCs ("no template controls") were included for every primer pair. Optimized primer concentrations per each gene are described in Table 3. After each run a melt curve analysis was performed to determine if a single product (i.e. the specific gene) was amplified. Standard curves of 10fold serial dilutions were conducted to estimate the amplification efficiency and the linearity $\left(\mathrm{r}^{2}\right)$, according to the MIQE guidelines (Bustin et al., 2009) with efficiency ranging between $90-105 \%$ and linearity greater than $r^{2}=0.98$ (Table 3 ). Gene expression was estimated with the relative quantification method, gadph and $\beta$-Act were used as references genes after assessing their stability as endogenous genes with qBase+ software (Biogazelle, UK). geNorm analysis (software qBase+) was used to calibrate and normalize the relative quantities (CNRQs) of the gene of interest expression ( $h s p 70)$.

\section{Long-term effects on reproduction ( 10 months)}

For the long-term exposure, a group of 35 gastropods (17-18 specimens per tank) were exposed to control and climate change conditions, respectively, to estimate the effects on reproduction (i.e. reproductive output) for an experimental period of 10 months. The beginning of the experimental period started when females finished their reproductive cycle and started a new one. The sexual ratio in the tanks was 4:6 M:F. 
Two-way repeated measures ANOVA were used to compare the impact of high temperature and $p \mathrm{CO}_{2}$ on growth (shell length and wet weight) and routine metabolic rates at regular intervals $(0,15,50,95$ and 135 days) followed by Holm-Sidak method post hoc analysis. Two-way ANOVA was used to analyse the ingestion rate and relative expression of $h s p 70$ between control and stressed gastropods followed by Tukey post hoc analysis. Normality and homogeneity of variance were confirmed before respective analysis and statistical significance was identified at $p<0.05$.

\section{Results And Discussion}

The physiological impact of high temperature and $p \mathrm{CO}_{2}$ on marine ectotherms are species-specific (Foo et al., 2012; Kroeker et al., 2013) and largely depend on the physiological plasticity that such organisms have to acclimate to rapid environmental changes (e.g. climate change). The principal aim of this study was to determine the short and long-term effects on gastropods exposed to future ocean conditions ( +3 ${ }^{\circ} \mathrm{C}$ above normal and $900 \mu \mathrm{atm} \mathrm{CO}_{2}$ ). Our results showed that $O$. erinaceus adults were able to physiologically acclimate after 95 days of exposure when not food limited. However, after prolonged exposure to modified conditions, snails showed negative impacts on reproduction. After 10-months, reproduction ceased, which shows that $O$. erinaceus could be at risk of population decline and/or local extinction under future climate conditions.

The first fifty days of exposure to high $\mathrm{T}^{\circ} / p \mathrm{CO}_{2}$ affected gastropod physiology, with a slight increase in routine metabolic rate and a decrease in growth rate (Fig. 1a,b, Table 4). Increases in metabolic rates have been reported in several marine ectotherms exposed to high $p \mathrm{CO}_{2}$ with limited extracellular $\mathrm{pH}$ regulatory capacity, such as molluscs and echinoderms (Kroeker et al., 2013). For example, Uthicke et al., (2014) found, after ten weeks of exposure to high $\mathrm{T}^{\circ} / \mathrm{pCO}_{2}$ (i.e. $+3{ }^{\circ} \mathrm{C}$ and $963 \mu \mathrm{atm} \mathrm{CO}_{2}$ ), an increase in metabolic demands and a decrease in growth rates in the Pacific sea urchin Echinometra sp. Similarly, adults of the temperate intertidal gastropod Littorina littorea exposed for 30 days to elevated temperature and $p \mathrm{CO}_{2}$ concentration $\left(+5{ }^{\circ} \mathrm{C}, 1000 \mu \mathrm{atm} \mathrm{CO}_{2}\right.$ ) showed lower shell growth rates, reduction on shell thickness and increase in ATP production (Melatunan et al., 2013). Therefore, the slight increase in metabolic rate observed during the first fifty days could be the result of the maintenance of internal homeostasis. The increased homeostasis is energetically demanding, thus, it can be concluded that tissue catabolism provided the necessary energy for homeostasis.

After 95 days of exposure, 0 . erinaceus adults showed full acclimation to the experimental conditions (Fig. 1a,b). Gastropods exposed to high $\mathrm{T}^{\circ} / \mathrm{pCO}_{2}$ recovered, growing at similar rates and exhibiting similar 
metabolic rates compared to control gastropods $(p>0.05)$. The ingestion rate increased in both experimental groups; however, a slight increase was observed in snails exposed to high $\mathrm{T}^{\circ} / p \mathrm{CO}_{2}$ (Fig. $1 \mathrm{c}$ ). Thus, snails can acclimate through an increase in food intake. Indeed, a meta-analysis conducted on the role of food supply in marine calcifiers (i.e. corals, molluscs and echinoderms) under acidified and warming conditions found that the negative effects of climate change on growth and calcification rates decreased when there are sufficient food resources (Ramajo et al., 2016). For example, calcification rates in juveniles of the blue mussel Mytilus edulis were not affected by high $p \mathrm{CO}_{2}$ (i.e. from 1000 to 3000 Matm $\mathrm{CO}_{2}$ ) when food supply was abundant (Thomsen et al., 2013). Conversely, food deprivation in the marine copepods Calanus sp. exposed to climate change conditions $\left(+2{ }^{\circ} \mathrm{C}\right.$ and $\left.1000 \mu a t m \mathrm{CO}_{2}\right)$ exacerbated the impact of temperature and $p \mathrm{CO}_{2}$ on their physiology (Mayor et al., 2015). Therefore, our study showed that $O$. erinaceus likely increased feeding rates to compensate for the increased metabolic rate. Thus, so long as food resources remain abundant, $O$. erinaceus adult could acclimate to future climate conditions. However, if food is no longer abundant (e.g. climate change effects in the abundance of other calcifying prey species like mussels or oysters), gastropods are unlikely to compensate and will be at risk in future acidified and warming scenarios.

Most coastal and estuarine species are already experiencing natural variation in seawater chemistry with temperature, dissolved oxygen and $\mathrm{pH}$ values that are projected at the end of this century (Duarte et al., 2013; Hofmann et al., 2011). Ocenebra erinaceus from the Solent population inhabit a flooded river-valley estuarine system experiencing natural short-term fluctuations in $\mathrm{pH}$ and temperature (e.g. from river discharges; Shi, 2000). The full acclimation observed in stressed gastropods show that $O$. erinaceus adults have developed physiological strategies to cope with fluctuating environments. At a molecular level, $h s p 70$ gene expression in gill tissue was not significantly different between control and snails exposed to high $\mathrm{T}^{\circ} / p \mathrm{pO}_{2}(\mathrm{Fig}, 1 \mathrm{~d}, \mathrm{p}>0.05)$. Hsp70 expression has been widely used to study the acute effects of temperature and acidification on organisms because of their protective and restorative function against damage or denaturation (Whiteley and Mackenzie, 2016). For example, high temperatures increased the $h s p 70$ expression after 5 days of exposure in gills of the blue mussel Mytilus edulis (Tedengren et al., 2000) or high $p \mathrm{CO}_{2}\left(\sim 1500 \mu \mathrm{atm} \mathrm{CO}_{2}\right)$ increased the expression after 72 hours in juveniles of the neogastropod Concholepas concholepas (Lardies et al., 2014). Few studies have attempted to study the combined effects of temperature and $p \mathrm{CO}_{2}$ on $h s p 70$ expression. For example, Liu et al., (2012) conducted an acute exposure for 96 hours to elevated temperature (+ $3 \mathrm{C}$ ) and elevated pCO2 ( 1400 $\left.\mu \mathrm{atm} \mathrm{CO}_{2}\right)$ in the pearl Oyster Pinctada fucata. They found that warming and acidified seawater conditions activated $h s p 70$ expression. After 24 hours, the impacts of these two stressors were synergistic; $p \mathrm{CO}_{2}$ exposure aggravated the sensitivity to temperature in $P$. fucata. After 96 hours, the expression decreased as a result of the decrease in the energy budget to meet the energy requirements for hsp70 gene expression (Liu et al., 2012). 
Two hypotheses can be suggested to explain why there were no effects on $h s p 70$ expression:

(1) gill cells of gastropods exposed to high $\mathrm{T}^{\circ} / p \mathrm{CO}_{2}$ could have activated the heat shock response (i.e. hsp70) during the first hours and days after the shock stress; however, $h s p 70$ gene expression in this study was measured 15 days after first exposure, thus, it was undetectable. Alternately,

(2) the temperature and alkalinity stress ( $\mathrm{high} \mathrm{T}^{\circ} / p \mathrm{CO}_{2}$ ) on gill cells of $O$. erinaceus was insufficient to activate the $h s p 70$ shock response. Ocenebra erinaceus adults were very tolerant to high $\mathrm{T}^{\circ} / p \mathrm{CO}_{2}$ in all the physiological variables studied in this study; therefore, to activate the heat shock response, it may be concluded that a more extreme stressful environment must be imposed.

Previous reports have suggested that HSP70 is a suitable stress biomarker because it is ubiquitous, highly conserved in almost all organisms and sensitive to stress (Tomanek and Somero 1999). However, there are some limitations to consider, for example: the time after initial stress exposure, duration of the stress, ontogenetic stage, number of environmental stressors that are producing stress, what form of HSP70 is expressed, amongst others (Morris et al., 2013). Therefore, the expression of HSP70 can be induced by a wide range of factors, which make them not suitable for estimating environmental stress in organisms.

After long-term exposure (i.e. 10-months) to future ocean conditions, females did not lay eggs under future ocean conditions. Under control conditions, six females laid $1525 \pm 269$ eggs each, which is coincident with previous estimations (Mardones et al., 2020). A possible explanation for this result could be that energetic demands of life under future conditions were so high that females exposed to high $\mathrm{T} / p \mathrm{CO}_{2}$ only invested energy in survival instead of reproduction. By comparison, histological examination of female gonads of the Pacific sea urchin Echinometra sp. exposed to similar experimental conditions used in this study, identified that females were unable to generate new cohorts of gametes, as eggs were degenerate and/or reabsorbed (Uthicke et al., 2014). Although, sea urchin females were exposed only for 10 weeks, and possibly the effects observed might be the result of experimental stress, the results could explain the observation made after 10 months in 0 . erinaceus females. Ocenebra erinaceus is species that only exhibits one reproductive peak per year (Martel et al., 2004); thus, the cessation of reproduction in stressed females could directly impact the maintenance of the Solent population in the future. However, in order to determine the impact of future ocean conditions on the species, more comparative studies among geographic populations are needed.

Our study showed that adults of 0 . erinaceus adults are able to fully compensate for the effects of high temperature and $p \mathrm{CO}_{2}$ (RCP8.5 climate change sceneries) if food resources are unlimited. After 95 days 
of exposure, all the physiological variables measured in this study were no longer affected, which means that stressed snails can physiologically acclimate. However, full acclimation of $O$. erinaceus came with high energetic demands resulting in high ingestion rates. After ten months of exposure, reproduction ceased under climate change conditions demonstrating that adults invested energy toward survival and not in reproduction. Under future climate conditions, 0 . erinaceus populations could decline, or even become locally extinct. Therefore, the implications of this study suggest that there is a need for the scientific community to assess the impact of climate change on appropriate time scales taking into account the combined results of both short- and long-term experiments and using multiple metrics of animal performance; which in turn will help us to develop accurate projections to manage the ecological consequences of climate change.

\section{Declarations}

Acknowledgements The authors would like to thank Ms. Nicola Pratt for her insights on the molecular analysis and Mr. R. Robinson for helping with the setup of experiments at the NOCS. This work was funded by the National Agency for Research and Development (ANID)/DOCTORADO BECAS CHILE/ 2015-72160099 and the University of Southampton.

Data availability The data generated and analysed during this study are available from the corresponding author upon request.

\section{Compliance with ethical standards}

Conflict of interest All authors declare that they have no conflict of interest on connection with this study.

Ethical approval Permission to conduct the fieldwork and collect samples was granted by the National Oceanographic Centre (NOCS), Southampton, UK. No special animal ethics approval was needed.

\section{References}

Barton, A., Hales, B., Waldbusser, G.G., Langdon, C., \& Feely, R.A. (2012). The Pacific oyster, Crassostrea gigas, shows negative correlation to naturally elevated carbon dioxide levels: Implications for near-term ocean acidification effects. Limnology and Oceanography, 57, 698-710.

https://doi.org/10.4319/lo.2012.57.3.0698

Bopp, L., Resplandy, L., Orr, J.C., Doney, S.C., Dunne, J.P., Gehlen, M., Halloran, P., Heinze, C., llyina, T., Séférian, R., Tjiputra, J., \& Vichi, M. (2013). Multiple stressors of ocean ecosystems in the 21st century: Projections with CMIP5 models. Biogeosciences, 10, 6225-6245. https://doi.org/10.5194/bg-10-62252013 
Bustin, S.A., Benes, V., Garson, J.A., Hellemans, J., Huggett, J., Kubista, M., Mueller, R., Nolan, T., Pfaffl, M.W., Shipley, G.L., Vandesompele, J., and Wittwer, C.T. (2009). The MIQE guidelines: Minimum information for publication of quantitative real-time PCR experiments. Clinical Chemistry 55, 611-622. https://doi.org/10.1373/clinchem.2008.112797

Crain, C.M., Kroeker, K., \& Halpern, B.S. (2008). Interactive and cumulative effects of multiple human stressors in marine systems. Ecology Letters, 11, 1304-1315. https://doi.org/10.1111/j.14610248.2008.01253.x

Chatzinikolaou E., Grigoriou P., Martini E. \& Aspasia S. 2019). Impacts of ocean acidification and warming on the feeding behaviour of two gastropod species. Mediterranean Marine Science, 20(4), 669-679. https://doi.org/10.12681/mms.19187

Duarte, C.M., Hendriks, I.E., Moore, T.S., Olsen, Y.S., Steckbauer, A., Ramajo, L., Carstensen, J., Trotter, J.A., \& McCulloch, M. (2013). Is Ocean Acidification an Open-Ocean Syndrome? Understanding Anthropogenic Impacts on Seawater pH. Estuaries and Coasts 36, 221-236. https://doi.org/10.1007/s12237-013-9594-3

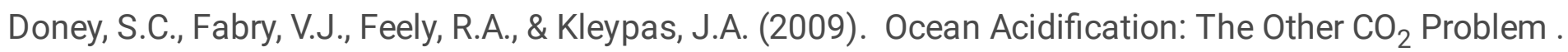
Annual Review of Marine Science, 1, 169-192. https://doi.org/10.1146/annurev.marine.010908.163834

Dupont, S., Dorey, N., Stumpp, M., Melzner, F., \& Thorndyke, M. (2013). Long-term and trans-life-cycle effects of exposure to ocean acidification in the green sea urchin Strongylocentrotus droebachiensis. Marine Biology 160, 1835-1843. https://doi.org/10.1007/s00227-012-1921-x

Feely, R.A., Sabine, C.L., Lee, K., Berelson, W., Kleypas, J., Fabry, V.J., and Millero, F.J. (2004). Impact of Anthropogenic $\mathrm{CO}_{2}$ on the $\mathrm{CaCO}_{3}$ System in the Oceans. Science 305, 362-366.

https://doi.org/10.1126/science.1097329

Foo, S.A., Dworjanyn, S.A., Poore, A.G.B., \& Byrne, M. (2012). Adaptive capacity of the habitat modifying sea urchin Centrostephanus rodgersii to ocean warming and ocean acidification: Performance of early 
embryos. PLoS ONE 7. https://doi.org/10.1371/journal.pone.0042497

Gattuso, J.P., Magnan, A., Billé, R., Cheung, W.W.L., Howes, E.L., Joos, F., Allemand, D., Bopp, L., Cooley, S.R., Eakin, C.M., Hoegh-Guldberg, O., Kelly, R.P., Pörtner, H.O., Rogers, A.D., Baxter, J.M., Laffoley, D., Osborn, D., Rankovic, A., Rochette, J., Sumaila, U.R., Treyer, S., \& Turley, C. (2015). Contrasting futures for ocean and society from different anthropogenic $\mathrm{CO} 2$ emissions scenarios. Science, 349,aac4722. https://doi.org/10.1126/science.aac4722

Godbold J.A. \& Solan M. (2013). Long-term effects of warming and ocean acidification are modified by seasonal variation in species responses and environmental conditions. Philosophical transactions of the Royal Society B, 368:20130186. https://doi.org/10.1098/rstb.2013.0186

Hauton, C., Tyrrell, T., \& Williams, J. (2009). The subtle effects of sea water acidification on the amphipod Gammarus locusta. Biogeosciences 5, 1479-1489. https://doi.org/10.5194/bg-6-1479-2009

Harvey, B.P., Gwynn-Jones, D., \& Moore, P.J. (2013). Meta-analysis reveals complex marine biological responses to the interactive effects of ocean acidification and warming. Ecology and Evolution, 3, 10161030. https://doi.org/10.1002/ece3.516

Hofmann, G. E., Smith, J.E., Johnson, K.S., Send, U., Levin, L.A., Micheli, F., Paytan, A., Price, N.N., Peterson, B., Takeshita, Y., Matson, P.G., de Crook, E., Kroeker, K.J., Gambi, M.C., Rivest, E.B., Frieder, C.A., Yu, P.C., \& Martz, T.R. (2011). High-frequency dynamics of ocean pH: A multi-ecosystem comparison. PLoS ONE 6(12): e28983. https://doi.org/10.1371/journal.pone.0028983

Hofmann, G.E., \& Todgham, A. (2010). Living in the Now: Physiological Mechanisms to Tolerate a Rapidly Changing Environment. Annual Review of Physiology, 72, 127-145. https://doi.org/10.1146/annurevphysiol-021909-135900

IPCC (2013) Climate change 2013: The Physical Science Basis. Contribution of working group I to the fifth assessment report of the intergovernmental panel on climate change, Cambridge, United Kingdom and New York, NY, USA. https://doi.org/10.1017/CBO9781107415324 
Kelly, M.W., Sanford, E., \& Grosberg, R.K., (2012). Limited potential for adaptation to climate change in a broadly distributed marine crustacean. Proceedings of the Royal Society Part B, 279, 349-356. https://doi.org/10.1098/rspb.2011.0542

Kroeker, K.J., Kordas, R.L., Crim, R., Hendriks, I.E., Ramajo, L., Singh, G.S., Duarte, C.M., and Gattuso, J.P. (2013). Impacts of ocean acidification on marine organisms: Quantifying sensitivities and interaction with warming. Global Change Biology, 19, 1884-1896. https://doi.org/10.1111/gcb.12179

Kroeker, K.J., Kordas, R.L., Crim, R.N., \& Singh, G.G. (2010). Meta-analysis reveals negative yet variable effects of ocean acidification on marine organisms. Ecology Letters, 13, 1419-1434. https://doi.org/10.1111/j.1461-0248.2010.01518.x

Lardies, M.A., Arias, M.B., Poupin, M.J., Manríquez, P.H., Torres, R., Vargas, C.A., Navarro, J.M., \& Lagos, N.A. (2014). Differential response to ocean acidification in physiological traits of Concholepas concholepas populations. Journal of Sea Research, 90, 127-134. https://doi.org/10.1016/j.seares.2014.03.010

Lewis, E. R., \& Wallace, D. W. R. (1998). Program Developed for CO2 System Calculations. United States. https://doi.org/10.15485/1464255

Liu, W., Huang, X., Lin, J., \& He, M. (2012). Seawater acidification and elevated temperature affect gene expression patterns of the pearl oyster Pinctada fucata. PLoS ONE 7(3): e33679. https://doi.org/10.1371/journal.pone.0033679

Mardones, M.L., Fenberg, P.B., Thatje, S. \& Hauton, C. (2020). Intraspecific plasticity and transgenerational adaptation of reproductive traits and early development in a temperate marine neogastropod. Marine Environmental Research, 161, 105123.

https://doi.org/10.1016/j.marenvres.2020.105123

Martel, C., Guarini, J.M., Blanchard, G., Sauriau, P.G., Trichet, C., Robert, S., \& Garcia-Meunier, P. (2004). Invasion by the marine gastropod Ocinebrellus inornatus in France. III. Comparison of biological traits 
with the resident species Ocenebra erinacea. Marine Biology 146, 93-102.

https://doi.org/10.1007/s00227-004-1421-8

Mayor, D.J., Sommer, U., Cook, K.B., \& Viant, M.R. (2015). The metabolic response of marine copepods to environmental warming and ocean acidification in the absence of food. Scientific Reports, 5, 1-12. https://doi.org/10.1038/srep13690

Meinshausen, M., Smith, S.J., Calvin, K., Daniel, J.S., Kainuma, M.L.T., Lamarque, J., Matsumoto, K., Montzka, S.A., Raper, S.C.B., Riahi, K., Thomson, A., Velders, G.J.M., \& van Vuuren, D.P.P. (2011). The RCP greenhouse gas concentrations and their extensions from 1765 to 2300. Climatic Change, 109, 213. https://doi.org/10.1007/s10584-011-0156-z

Metzger, R., Sartoris, F.J., Langenbuch, M., \& Pörtner, H.O. (2007). Influence of elevated $\mathrm{CO}_{2}$ concentrations on thermal tolerance of the edible crab Cancer pagurus. Journal of Thermal Biology 32, 144-151. https://doi.org/10.1016/j.jtherbio.2007.01.010

Melatunan, S., Calosi, P., Rundle, S.d., Widdicombe, S., Moody, A.J. (2013). Effects of ocean acidification and elevated temperature in shell plasticity and its energetic basis in an intertidal gastropod. Marine Ecology Progress Series, 472, 155-168. https://doi.org/10.3354/meps10046

Michaelidis, B., Ouzounis, C., Paleras, A., \& Pörtner, H.O. (2005). Effects of long-term moderate hypercapnia on acid-base balance and growth rate in marine mussels Mytilus galloprovincialis. Marine Ecology Progress Series, 293, 109-118. https://doi.org/10.3354/meps293109

Morris, J.P., Thatje, S., \& Hauton, C. (2013). The use of stress-70 proteins in physiology: A re-appraisal. Molecular Ecology, 22, 1494-1502. https://doi.org/10.1111/mec.12216

Nagelkerken, I., \& Munday, P.L. (2016). Animal behaviour shapes the ecological effects of ocean acidification and warming: Moving from individual to community-level responses. Global Change Biology, 22, 974-989. https://doi.org/10.1111/gcb.13167 
Navarro, J.M., Leiva, G.E., Gallardo, C.S., \& Varela, C. (2002). Influence of diet and temperature on physiological energetics of Chorus giganteus (Gastropoda: Muricidae) during reproductive conditioning. New Zealand Journal of Marine and Freshwater Research, 36(2), 321-332. https://doi.org/10.1080/00288330.2002.9517089

Orr, J.C., Fabry, V.J., Aumont, O., Bopp, L., Doney, S.C., Feely, R.A., Gnanadesikan, A., Gruber, N., Ishida, A., Joos, F., Key, R.M., Lindsay, K., Maier-Reimer, E., Matear, R., Monfray, P., Mouchet, A., Najjar, R.G., Plattner, G.K., Rodgers, K.B., Sabine, C.L., Sarmiento, J.L., Schlitzer, R., Slater, R.D., Totterdell, I.J., Weirig, M.F., Yamanaka, Y., \& Yool, A. (2005). Anthropogenic ocean acidification over the twenty-first century and its impact on calcifying organisms. Nature, 437, 681-686. https://doi.org/10.1038/nature04095

Parker, L.M., Ross, P., O'Connor, W., Pörtner, H., Scanes, E., \& Wright, J. (2013). Predicting the Response of Molluscs to the Impact of Ocean Acidification. Biology, 2, 651-692. https://doi.org/10.3390/biology2020651

Pörtner, H.O. (2008). Ecosystem effects of ocean acidification in times of ocean warming: A physiologist's view. Marine Ecology Progress Series, 373, 203-217. https://doi.org/10.3354/meps07768

Ramajo, L., Pérez-León, E., Hendriks, I.E., Marbà, N., Krause-Jensen, D., Sejr, M.K., Blicher, M.E., Lagos, N.A., Olsen, Y.S., \& Duarte, C.M. (2016). Food supply confers calcifiers resistance to ocean acidification. Scientific Reports, 6, 1-6. https://doi.org/10.1038/srep19374

Riebesell U., Fabry V. J., Hansson L. \& Gattuso J.-P. (eds) (2011) Guide to best practices for ocean acidification research and data reporting. [reprinted edition including erratum]. Luxembourg, Publications Office of the European Union, 258pp. (EUR 24872 EN). https://doi.org/10.2777/66906

Rühl S., Calosi P., Faulwetter S., Keklikoglow K., Widdicombe S. \& Queirós A.M. (2017). Long-term exposure to elevated $\mathrm{pCO}_{2}$ more than warming modifies early-life shell growth in a temperate gastropod. Journal of Marine Science, 74(4), 113-1124. https://doi.org/10.1093/icesjms/fsw242 
Shi, L. (2000) Development and application of a three-dimensional water quality model in a partiallymixed estuary, Southampton Water, UK. Phd diss., University of Southampton.

Smith, K.E., Reed, A.J., \& Thatje, S. (2015). Intracapsular development and dispersal polymorphism in the predatory gastropod Ocenebra erinaceus (Linnaeus 1758). Helgoland Marine Research 69, 249-258. https://doi.org/10.1007/s10152-015-0433-8

Somero, G.N. (2002). Thermal physiology and vertical zonation of intertidal animals: Optima, limits, and costs of living. Integrative and Comparative Biology, 42, 780-789. https://doi.org/10.1093/icb/42.4.780

Tomanek, L., \& Somero, G.N. (1999). Evolutionary and acclimation-induced variation in the heat-shock responses of congeneric marine snails (genus Tegula) from different thermal habitats: Implications for limits of thermotolerance and biogeography. Journal of Experimental Biology, 202, 2925-2936.

Thomsen, J., Casties, I., Pansch, C., Körtzinger, A., \& Melzner, F. (2013). Food availability outweighs ocean acidification effects in juvenile Mytilus edulis: Laboratory and field experiments. Global Change Biology, 19, 1017-1027. https://doi.org/10.1111/gcb.12109

Uthicke, S., Liddy, M., Nguyen, H.D., \& Byrne, M. (2014). Interactive effects of near-future temperature increase and ocean acidification on physiology and gonad development in adult Pacific sea urchin, Echinometra sp. A. Coral Reefs, 33, 831-845. https://doi.org/10.1007/s00338-014-1165-y

Whiteley, N., \& Mackenzie, C. (2016). Physiological responses of marine invertebrates to thermal stress. In Stressors in the Marine Environment: Physiological and ecological responses; societal implications. : Oxford University Press. https://doi.org/10.1093/acprof:oso/9780198718826.001.0001

Zhang H., Shin P.K.S \& Cheung S.G. (2015) Physiological responses and scope for growth upon mediumterm exposure to the combined effects of ocean acidification and temperature in a subtidal scavenger Nassarius conoidalis. Marine Environmental Research, 106, 51-60.

https://doi.org/10.1016/j.marenvres.2015.03.001

Page 16/20 


\section{Tables}

Table 1. Environmental seawater parameters for control and high $\mathrm{T}^{\circ} / \mathrm{pCO}_{2}$ in adult gastropods (Ocenebra erinaceus) exposed to short and long-term exposures. All parameters were measure each fortnight. (DIC) means dissolved inorganic carbon. ' $\Omega$ ca' means the saturation state of calcite minerals, ' $\Omega$ ar' means the saturation state of aragonite minerals. Values are given as mean \pm standard deviation.

\begin{tabular}{|lllll|}
\hline Parameters & Short-term & & Long-term & \\
\hline & Control & High $\mathrm{T}^{\circ} / \mathrm{pCO}_{2}$ & Control & High $\mathrm{T}^{\circ} / \mathrm{pCO}{ }_{2}$ \\
\hline $\mathrm{pH}$ & $8.022 \pm 0.2$ & $7.678 \pm 0.1$ & $8.114 \pm 0.04$ & $7.646 \pm 0.2$ \\
\hline Temperature $\left({ }^{\circ} \mathrm{C}\right)$ & $14.6 \pm 0.4$ & $17.2 \pm 0.2$ & $14.6 \pm 0.3$ & $17.3 \pm 0.2$ \\
\hline Salinity & $33.2 \pm 0.8$ & $33.4 \pm 0.5$ & $32.85 \pm 0.1$ & $33.65 \pm 0.21$ \\
\hline $\mathrm{pCO}_{2}(\mu \mathrm{atm})$ & $499 \pm 60$ & $1013 \pm 157$ & $475 \pm 9$ & $1072 \pm 120$ \\
\hline Total Alkalinity $\left(\mu \mathrm{mol} \mathrm{Kg}^{-1}\right)$ & $2314 \pm 71$ & $2221 \pm 52$ & $2104 \pm 164$ & $2232 \pm 290$ \\
\hline DIC $\left(\mu \mathrm{mol} \mathrm{Kg}{ }^{-1}\right)$ & $2140 \pm 79$ & $2146 \pm 71$ & $1936 \pm 150$ & $2136 \pm 238$ \\
\hline$\left[\mathrm{CO}_{3}{ }^{2}\right]\left(\mu \mathrm{mol} \mathrm{kg}{ }^{-1}\right)$ & $128 \pm 14$ & $76 \pm 11$ & $114 \pm 17$ & $65 \pm 30$ \\
\hline$\Omega \mathrm{ca}$ & $3.1 \pm 0.3$ & $1.8 \pm 0.2$ & $1.7 \pm 0.3$ & $1.55 \pm 0.7$ \\
\hline$\Omega$ ar & $2.0 \pm 0.2$ & $1.2 \pm 0.2$ & $2.7 \pm 0.4$ & $1.23 \pm 0.7$ \\
\hline
\end{tabular}

Table 2. Sequences used for alignments to design degenerate primers. Listed are the sequences, species name and accession numbers from the NCBI database. 'GOI' means gene of interest and 'ERG' means endogenous reference genes, 'SL' means aminoacidic sequence length. 
Protein Species names and accession numbers

name

HSP70 Pomacea canaliculata (KF356182) 906 SL ; Haliotis gigante (MF375339) 804 SL; Cellana

(GOI) toreuma (JX169849) 861 SL; Biomphalaria glabrata (AF025477) 1085 SL; Haliotis fulgens (MH220529) 827 SL; Pomacea caniculata (KM405321) 871 SL; Mytilus galloprovincialis (AY861684) 793 sl; Crassostrea gigas (AB122063) 743 SL; Rattus norvegicus (L16764) $810 \mathrm{SL}$

B-Actin $\quad$ Cepaea nemoralis (MH035489) 472 SL; Haliotis diversicolor (EU244396) 499 bp;

(ERG) Hypriopsis cumingii (HM045420) 479 SL, Loligo pealei (AY701849) 718 SL; Crassostrea brasiliana (KY707329) 377 SL; Azumapecten farreri (KJ081194) 613 SL; Gecarcinus lateralis (L76943) 463 SL; Penaeus monodon (MG775230) 434 SL; Macaca mulatta (NM_001033084) 523 SL; Pan troglodytes (AB188274) 610 SL

GAPDH Homo sapiens (AF261085) 434 SL; Cryptocercus punctulatus (JQ686947) 439 SL; Bufo (ERG) gargarizans (KX698086) 381 SL; Scophthalmus maximus (KU057925) 435 SL

Table 3. Summary of real-time PCR primers and validated optimal reactions conditions. (F) Forward; (R) Reverse; (AC) Assay concentration; (AS) Amplicon size; (RF) Reaction efficiency; (Tm) melting temperatures; $\left(R^{2}\right)$ coefficient of determination.

\begin{tabular}{|c|c|c|c|c|c|c|c|}
\hline $\begin{array}{l}\text { Gene } \\
\text { assay }\end{array}$ & Sequence & $\begin{array}{l}\mathrm{Tm} \\
\left({ }^{\circ} \mathrm{C}\right)\end{array}$ & $\begin{array}{l}\mathrm{AC} \\
(\mathrm{nM})\end{array}$ & $\begin{array}{l}\text { AS } \\
(n t)\end{array}$ & RF & Regression relation & $\mathrm{R}^{2}$ \\
\hline hsp70 & $\begin{array}{l}\text { F: } \\
\text { GCTTCTGGATCTTAGGGATAC } \\
\text { R: } \\
\text { GCCAGTGGAGAAGTCTATG }\end{array}$ & 59 & $\begin{array}{l}50 \\
300\end{array}$ & 101 & 1.7 & $\begin{array}{l}\mathrm{Cq}=(-4.315 \times \mathrm{log} \\
\text { dilution })+21.04\end{array}$ & 0.99 \\
\hline$\beta$-act & $\begin{array}{l}\text { F: CTTCGTTCCTGGGTATGG } \\
\text { R: } \\
\text { GTACAGGTCTTTACGGATGT }\end{array}$ & 59 & $\begin{array}{l}50 \\
300\end{array}$ & 92 & 1.8 & $\begin{array}{l}\mathrm{Cq}=(-3.6895 \times \mathrm{log} \\
\text { dilution })+23.23\end{array}$ & 0.97 \\
\hline gapdh & $\begin{array}{l}\text { F: GTGACGCTCAACAAAGAAG } \\
\text { R: TCTGTGTAGCCCATGAATC }\end{array}$ & 58 & $\begin{array}{l}50 \\
300\end{array}$ & 95 & 1.9 & $\begin{array}{l}\mathrm{Cq}=(-3.4070 \times \log \\
\text { dilution })+22.55\end{array}$ & 0.93 \\
\hline
\end{tabular}

Table 4. Summary of two-way repeated measures ANOVA for growth (shell and wet weight), routine metabolic rate, ingestion rate and $h s p 70$ expression in adult snails (Ocenebra erinaceus) exposed to control and high $\mathrm{T}^{\circ} / p \mathrm{CO}_{2}$ within and between experimental intervals $(0,15,50,95,135$ days). Factors: 
'Group' (control or climate change conditions) and 'Exp. Days' (experimental days). Source of variation (source), degrees of freedom (df), variance ratios (F).

\begin{tabular}{|lllll|}
\hline Variable & Source & $\mathrm{df}$ & $\mathrm{F}$ & $\mathrm{p}$ \\
\hline Shell length rate & Group & 1 & 0.212 & 0.65 \\
& Exp. Day & 3 & 1.116 & 0.35 \\
\hline Weight rate & Interaction & 3 & 0.130 & 0.94 \\
\hline & Group & 1 & 5.94 & $\mathbf{0 . 0 3}$ \\
\hline OCR & Exp. Day & 3 & 1.074 & 0.371 \\
\hline & Interaction & 3 & 3.554 & $\mathbf{0 . 0 2}$ \\
\hline Ingestion rate & Group & 1 & 0.382 & 0.547 \\
\hline & Exp. Day & 4 & 1.385 & 0.252 \\
\hline & Exp. Day & 1 & 2.611 & 0.112 \\
\hline hsp70 & 3 & 6.141 & $\mathbf{0 . 0 0 1}$ \\
\hline & Interaction & 3 & 0.437 & 0.727 \\
\hline & Group & 2 & 0.111 & 0.741 \\
\hline & Exp. Day & 1 & 8.400 & $\mathbf{0 . 0 0 1}$ \\
\hline Interaction & 2 & 0.243 & 0.786 \\
\hline
\end{tabular}

Figures 

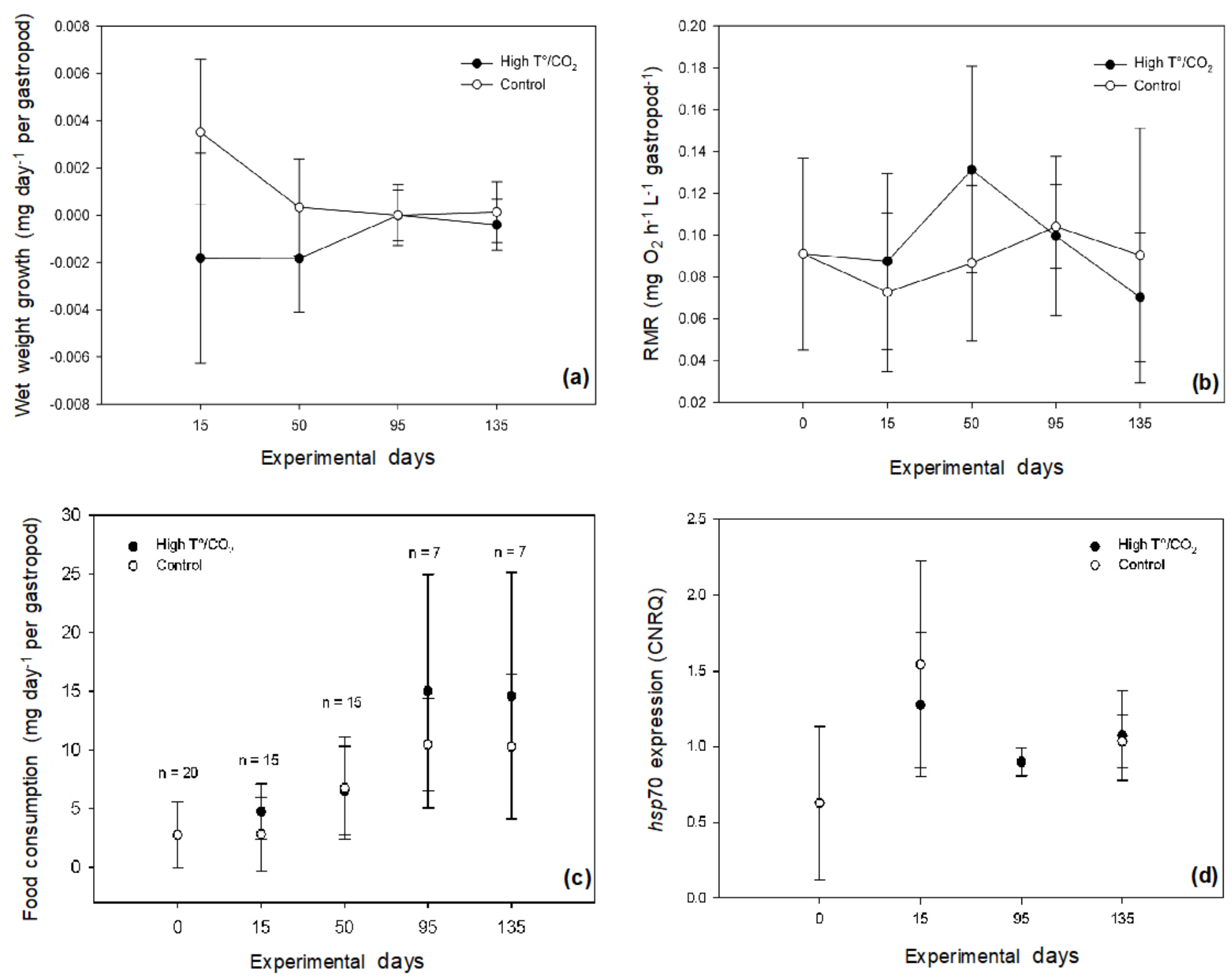

\section{Figure 1}

(a) Wet weight growth ( $n=5$ control, $n=10$ stressed snails per experimental interval), (b) Routine metabolic rate ( $\mathrm{n}=5$ control, $\mathrm{n}=10$ stressed snails per experimental interval), (c) Ingestion rate (mg of dry meat mussel) and (d) Relative quantities (CNRQ) of the hsp70 gene in gill tissues ( $\mathrm{n}=8$ control, $\mathrm{n}=8$ stressed snails per experimental interval) in Ocenebra erinaceus adults exposed to control $\left(14{ }^{\circ} \mathrm{C}-400\right.$

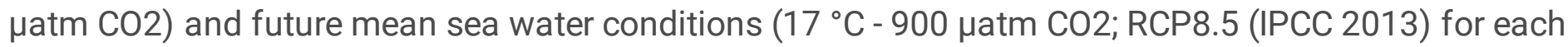
intervals of the experimental period. Values are given as mean and standard deviation. 